Jurnal Info Kesehatan

Vol 16, No.2, Desember 2018, pp. 214-225

P-ISSN 0216-504X, E-ISSN 2620-536X

Journal DOI: https://doi.org/10.31965/infokes

Website: http://jurnal.poltekeskupang.ac.id/index.php/infokes

RESEAR C H

Open Access

\title{
Hubungan Inisiasi Menyusu Dini Dengan Pemberian Asi Ekslusif Pada Bayi
}

\author{
Sofia Mawaddah \\ Kebidanan, Poltekkes Palangkaraya \\ Jl.G.Obos no. 32 palangkaraya \\ e-mail: sofizline@gmail.com
}

\begin{abstract}
Abstrak
Latar belakang: Angka Kematian Bayi (AKB) merupakan salah satu indikator penting dalam menentukan tingkat kesehatan masyarakat. Menurut Bappenas (2015), faktor penyebab utama kematian bayi di Indonesia adalah kematian neonatal sebesar $46,2 \%$, diare sebesar $15,0 \%$, pneumonia sebesar $12,7 \%$ dan status kesehatan bayi $17,8 \%$. Untuk menekan angka kematian bayi, salah satunya adalah dengan Inisiasi Menyusu Dini (IMD) dan dilanjutkan dengan pemberian ASI secara eksklusif sampai bayi berusia 6 bulan. Profil kesehatan Kalimantan Tengah tahun 2015 masih sekitar 27,58\% bayi yang mendapatkan Asi Ekslusif. Profil Kabupaten Katingan tahun 2016 tercatat 15,84\% bayi (profil kesehatan kab.Katingan 2016). Tujuan: mengetahui hubungan inisiasi menyusu dini dengan keberhasilan pemberian Asi Ekslusif. Metode Penelitian: Cross sectional. Teknik pengambilan sampel : nonprobability sampling jenisnya puposive sampling yaitu 50 sampel serta menggunakan uji Chi-Squere. Hasil: Uji statistik didapatkan nilai $p=0,001$. Hal ini menunjukkan terdapat hubungan antara variabel IMD (Inisisasi Menyusu Dini) dengan Pemberian Asi Eksklusif ( $p<0,05)$.Nilai OR 9,17 (95\%CT) menunjukkan bahwa responden yang tidak diberikan inisiasi menyusu dini 9,17 kali lebih beresiko tidak mendapatkan asi eksklusif dibandingkaan dengan responden yang dilakukan inisiasi menyusu dini. Kesimpulan: Terdapat Hubungan antara Inisiasi Menyusu Dini dengan Keberhasilan Pemberian Asi Ekslusif pada bayi 0-6 bulan.
\end{abstract}

Kata Kunci: Inisiasi menyusu dini, Asi ekslusif 


\title{
The Relationship of Early Breastfeeding Initiation with Exclusive Breastfeeding for Babies
}

\begin{abstract}
Background: Infant Mortality Rate (IMR) is an important indicator in determining the level of public health. According to Bappenas (2015), the main causes of infant mortality in Indonesia are neonatal deaths by $46.2 \%$, diarrhea by $15.0 \%$, pneumonia by $12.7 \%$ and infant health status by $17.8 \%$. To reduce infant mortality, one of them is by Early Breastfeeding Initiation (IMD) and continued with exclusive breastfeeding until the baby is 6 months old. Central Kalimantan Health Profile 2015 is approximately $27.58 \%$ of infants who get Asi eksklusif. Profile of Katingan Regency in 2016 recorded $15.84 \%$ of infants (health profile of Katingan 2016). Objective: To determine the relationship of early initiation of breastfeeding with the successful provision of Asi eksklusif. Research methods: Cross-sectional. The sampling technique: non-probability sampling its kind purposive samplingof 50 samples and using Chi-Square. Results: Statistical test obtained $p=0.001$. This shows that there is a relationship between the variables of Early Breastfeeding Initiation and Exclusive Breastfeeding ( $\mathrm{p}<0.05)$. OR value 9.17 (95\% CT) indicates that respondents who were not given early breastfeeding initiation were 9.17 times more at risk do not get exclusive breastfeeding compared to respondents who carried out early breastfeeding initiation. Conclusion: There is a relationship between early breastfeeding initiation and exclusive breastfeeding success in infants 0-6 months.
\end{abstract}

Keywords: Early breastfeeding initiation, Exclusive breastfeeding

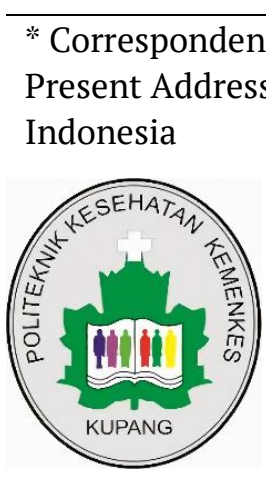

*Correspondence: sofizline@gmail.com

Present Address: Jl.G.Obos no. 32 palangkaraya, Indonesia

CThe Author(s) 2018. This article is distributed under the terms of the Creative Commons Attribution 4.0 International License (http://creativecommons.org/licenses/by/4.0/), which permits unrestricted use, distribution, and reproduction in any medium, provided you give appropriate credit to the original author(s) and the source, provide a link to the Creative Commons license, and indicate if changes were made. The Creative Commons Public Domain Dedication waiver (http://creativecommons.org/publicdomain/zero/1.0/) applies to the data made available in this article, unless otherwise stated. 


\section{PENDAHULUAN}

Di Negara berkembang, saat melahirkan dan minggu pertama setelah melahirkan merupakan periode kritis bagi ibu dan bayinya.Sekitar dua per tiga kematian terjadi pada masa neonatal. Dua pertiga kematian neonatal tersebut terjadi pada minggu pertama, dan dua per tiga kematian bayi pada minggu pertama tersebut terjadi pada hari pertama. Hasil SDKI tahun 2012 menunjukkan angka yang sama untuk Angka Kematian Neonatal yaitu sebesar 19 per 1000 kelahiran hidup, sedangkan menurut SDKI tahun 2007, AKB di Indonesia sebesar 34 per 1000 kelahiran hidup dan mengalami penurunan menjadi 32 per 1000 kelahiran hidup pada tahun 2012, namun AKB tersebut masih jauh dari target yang ingin dicapai sesuai tujuan MDGs yaitu 23 per 1000 kelahiran hidup pada tahun 2015.

Menurut Bappenas (2015), faktor penyebab utama kematian bayi di Indonesia adalah kematian neonatal sebesar $46,2 \%$, diare sebesar $15,0 \%$, pneumonia sebesar $12,7 \%$ dan status kesehatan bayi $17,8 \%$. Berbagai upaya memang telah dilakukan untuk menurunkan angka kematian ibu, bayi baru lahir, bayi dan balita, antara lain melalui penempatan bidan di desa, pemberdayaan keluarga dan masyarakat dengan menggunakan Buku Kesehatan Ibu dan Anak (Buku KIA) dan Program Perencanaan Persalinan dan Pencegahan Komplikasi (P4K), serta penyediaan fasilits kesehatan Pelayanan Obstetri
Neonata Emergensi Dasar (PONED) di Puskesmas perawatan dan Pelayanan Obstetri Neonatal Emergensi Komprehensif (PONEK) di rumah sakit. Untuk menekan angka kematian bayi, salah satunya adalah dengan Inisiasi Menyusu Dini (IMD) dan dilanjutkan dengan pemberian ASI secara eksklusif sampai bayi berusia 6 bulan. Keberhasilan pemberian ASI ekslusif berawal dari terlaksananya proses IMD secara optimal. Disamping menjadi titik awal keberhasilan ASI Eksklusif, IMD diyakini memiliki banyak manfaat bagi ibu yaitu saat sentuhan, hisapan, dan jilatan bayi pada puting ibu selama prosesinisiasimenyusu dini akan merangsang keluarnya hormon oksitosin yang menyebabkan rahim berkontraksi sehingga membantu pengeluaran plasenta dan mengurangi perdarahan pada ibu.(Jurnal Kesehatan Masyarakat Nasional Vol. 4, No. 3, 2009)

Kontak kulit membantu proses kolonisasi kulit,dimana bakteri yang menempel pada kulit ibu dan dijilat oleh bayi, diketahui bahwa bakteri tersebut bermanfaat bagi bayi, berperan sebagai zat antibodi untuk melindungi bayi dari kuman penyakit di lingkungan luar bayi. Menurut penelitian diketahui bahwa bayi yang diberi kesempatan menyusu dini akan berhasil menyusu eksklusif delapan kali lebih besar dibandingkan bayi yang tidak diberi kesempatan menyusu dini. Ini berarti bahwa bayi selanjutnya akan lebih mungkin untuk disusui sampai usianya mencapai dua tahun bahkan 
lebih Manfaat IMD baik bagi bayi maupun ibunya sangat besar.( Edmond, dkk balai penerbit jakarta :2009).

Di Kalimantan Tengah sendiri Asi Ekslusif masih tergolong rendah menurut Profil kesehatan tahun 2015 masih sekitar 27,58\% bayi yang mendapatkan Asi Ekslusif sampai bayi berumur 0-6 bulan, ditahun 2016 khususnya kecamatan Katingan Hilir menurut profil Kabupaten Katingan tercatat $15,84 \%$ bayi yang mendapat Asi Ekslusif persentase tersebut masih tergolong rendah keadaan ini di sebabkan berbagai faktor antaralain kesibukan ibu yang sering tidak sempat memberikan Asi Ekslusif dan berbagai faktor lainnya.(profil kesehatan kab.katingan 2016).

Berdasarkan Latar Belakang dan fenomena tersebut penulis terarik untuk meneliti tentang hubungan Inisiasi Menyusu Dini dengan keberhasilan pemberian Asi Ekslusif 0-6 bulan.

\section{DESAIN PENELITIAN}

Penelitian ini mengunakan desain penelitian cross sectional. Dengan pendekatan retrostektif.
WAKTU DAN TEMPAT PENELITIAN

Penelitian ini dilakukan di wilayah kerja Puskesmas Kereng Pangi Kecamatan Katingan Hilir Kabupaten Katingan dan dilaksanakan pada bulan Maret - Juni 2018.

\section{SAMPEL PENELITIAN}

Sampel dalam penelitian ini yaitu semua ibu yang memiliki bayi usia menyusui sebanyak 50 orang.

\section{INSTRUMEN PENELITIAN}

Instrumen yang digunakan dalam penelitian ini adalah wawancara, observasi dan format isian.

\section{TEKNIK PENGUMPULAN DATA}

Peneliti melakukan wawancara dengan ibu yang memiliki bayi usia 7-12 bulan yang datang ke posyandu dengan alat bantu format isian.

\section{TEKNIK ANALISIS DATA}

Teknik analisis data pada penelitian ini menggunakan analisis univariat dilakukan pada masing-masing variable yaitu IMD, Asi ekslusif, usia, pekerjaan, pendidikan dan analisis bivariat menggunakan uji chi square. 


\section{HASIL PENELITIAN}

\section{Analisis Univariat}

Tabel 1.Distribusi Frekuensi responden menurut umur, Pekerjaan, Pendidikan, Jenis Persalinan, Jumlah Anak, Riwayat ANC, IMD, dan Asi Eksklusif

\begin{tabular}{|c|c|c|c|}
\hline \multirow{6}{*}{$\begin{array}{l}\text { No. } \\
1 \\
\end{array}$} & Variabel & Frekuensi & Presentase \\
\hline & Umur & $\mathrm{f}$ & $\%$ \\
\hline & $<20$ Tahun & 1 & 2 \\
\hline & 20-35 Tahun & 41 & 82 \\
\hline & > 35 Tahun & 8 & 16 \\
\hline & Total & 50 & 100 \\
\hline \multirow[t]{5}{*}{2} & Pekerjaan & & \\
\hline & Ibu Rumah tangga & 39 & 76 \\
\hline & Swasta & 12 & 12 \\
\hline & Pegawai Negeri Sipil & 5 & 5 \\
\hline & Total & 50 & 100 \\
\hline \multirow[t]{7}{*}{3} & Pendidikan & & \\
\hline & SD & 7 & 14 \\
\hline & SMP & 19 & 38 \\
\hline & SMA & 17 & 34 \\
\hline & DIPLOMA & 4 & 8 \\
\hline & SARJANA & 3 & 6 \\
\hline & Total & 50 & 100 \\
\hline \multirow[t]{4}{*}{4} & Jenis Persalinan & & \\
\hline & Normal & 43 & 86 \\
\hline & Dengan tindakan: SC & 7 & 7 \\
\hline & Total & 50 & 100 \\
\hline \multirow[t]{5}{*}{5} & Jumlah Anak & & \\
\hline & Satu & 12 & 12 \\
\hline & Dua & 24 & 44 \\
\hline & $\geqslant$ Tiga & 22 & 32 \\
\hline & Total & 50 & 100 \\
\hline \multirow[t]{4}{*}{6} & Riwayat ANC & & \\
\hline & Pernah : Teratur & 48 & 96 \\
\hline & Pernah : Tidak Teratur & 2 & 4 \\
\hline & Total & 50 & $100 \%$ \\
\hline \multirow[t]{4}{*}{7} & IMD & & \\
\hline & Dilakukan & 26 & $52 \%$ \\
\hline & Tidak Dilakukan & 24 & $48 \%$ \\
\hline & Total & 50 & \\
\hline 8 & Asi Eksklusif & & \\
\hline
\end{tabular}




\begin{tabular}{lcc}
\hline Ya & 31 & 62 \\
Tidak & 19 & 38 \\
\hline Total & 50 & 100 \\
\hline
\end{tabular}

Berdasarkan tabel 1 didapatkan hasil umur responden yang terbanyak yaitu 20-35 tahun berjumlah 41 orang (82\%), pekerjaan ibu terbanyak yaitu ibu rumah tangga berjumlah 39 orang (76\%),pendidikan terakhir ibu terbanyak yaitu SMP berjumlah 19 orang (38\%),jenis persalinan yang terbanyak yaitu persalinan normal berjumlah 43 orang (86\%),jumlah anak yang dimiliki ibu terbanyak yaitu 2 anak berjumlah 24 orang (44\%),riwayat ANC yang terbanyak yaitu teratur berjumlah 48 orang (96\%),IMD yang dilakukan berjumlah 26 (52\%) dan yang melakukan Asi eksklusif berjumlah 31 (62\%).

\section{Analisis Bivariat}

Tabel 2. Hubungan Inisiasi Menyusu Dini dengan Pemberian Asi Esklusif

\begin{tabular}{|c|c|c|c|c|c|c|c|c|}
\hline \multirow{3}{*}{$\begin{array}{l}\text { Inisiasi } \\
\text { Menyusu Dini }\end{array}$} & \multicolumn{4}{|c|}{ Asi Esklusif } & \multirow{2}{*}{\multicolumn{2}{|c|}{ Jumlah }} & \multirow{3}{*}{$\begin{array}{l}\text { OR } \\
(95 \% \mathrm{CT})\end{array}$} & \multirow{3}{*}{$\begin{array}{l}P \text { - } \\
\text { value }\end{array}$} \\
\hline & \multicolumn{2}{|c|}{ Ya } & \multicolumn{2}{|c|}{ Tidak } & & & & \\
\hline & $\mathbf{F}$ & $\%$ & $\mathbf{F}$ & $\%$ & $\mathbf{n}$ & $\%$ & & \\
\hline Dilakukan & 22 & 84,6 & 4 & 15,4 & 26 & 100 & 9,17 & \\
\hline $\begin{array}{l}\text { Tidak } \\
\text { dilakukan }\end{array}$ & 9 & 37,5 & 15 & 62,5 & 24 & 100 & $\begin{array}{l}(2,38- \\
35,30)\end{array}$ & 0,001 \\
\hline Jumlah & 31 & & 19 & & 50 & & & \\
\hline
\end{tabular}

Berdasarkan tabel 2 didapatkan hasil responden yang dilakukan IMD dan berhasil asi eksklusif sebesar 88,6 \% dan tidak asi eksklusif sebesar 15,4\%, sedangkan ibu yang tidak dilakukan IMD yang tidak ASI eksklusif sebesar 62,5\% dan 37,5 \% Asi Eksklusif. Hasil uji statistik didapatkan nilai $\mathrm{p}=0,001$. Hal ini menunjukkan terdapat hubungan antara variabel IMD (Inisisasi Menyusu Dini) dengan Pemberian Asi Eksklusif dimana nilai $(\mathrm{p}<0,05)$ sehingga Hipotesis $\mathrm{H}_{\mathrm{a}}$ diterima bahwa Ada hubungan antara
Inisiasi Menyusu Dini dengan Keberhasilan Pemberian Asi Ekslusif pada bayi 0-6 bulan di wilayah Kerja Puskesmas Kereng Pangi. Nilai OR (95\%CT) menunjukkan bahwa responden yang tidak diberikan inisiasi menyusu dini 9,17 kali lebih beresiko tidak mendapatkan asi eksklusif dibandingkan dengan responden yang dilakukan inisiasi menyusu dini. 


\section{PEMBAHASAN}

Inisiasi menyusu dini mempunyai arti penting dalam merangsang produksi ASI dan memperkuat refleks menghisap bayi. Refleks menghisap awal pada bayi paling kuat dalam beberapa jam pertama setelah lahir dan meningkatkan lamanya bayi disusui. Oleh karena itu, inisiasi menyusui dini akan lebih bermanfaat untuk keberlanjutan pemberian ASI dibandingkan tidak inisiasi menyusui dini (Vetty dan Elmatris, 2011). Menurut Eddy Tiro, (2009) salah satu tujuan Inisiasi Menyusu Dini (IMD), yaitu: Mempercepat produksi ASI. Inisiasi menyusu dini dapat mengurangi $22 \%$ kematian bayi 28 hari. Sekitar $40 \%$ kematian bayi pada satu bulan pertama kehidupan bayi. Inisiasi menyusu dini meningkatkan keberhasilan menyusu ekslusif dan lama menyusu sampai dua tahun.

Berdasarkan tabel 1 menunjukan bahwa rata-rata tingkat pengetahuan menengah ke atas yaitu pendidikan SMP yaitu berjumlah 19 orang (38\%), SMA berjumlah 17 orang (34\%), Diploma berjumlah 4 orang (8\%) dan Sarjana berjumlah 3 orang (6\%). Hanya 7 orang (14\%) yang memiliki tingkat pengetahuan dasar.

Penelitian ini sejalan dengan penelitian yang dilakukan oleh Amin, dkk (2014) tentang Pengaruh Faktor Sosial Ibu terhadap Keberhasilan Menyusui pada Dua Bulan Pertama. Hasil penelitian ini menyimpulkan bahwa ibu dengan tingkat pendidikan tinggi, tidak bekerja, mempunyai pengetahuan yang baik, melaksanakan IMD, mempunyai dukungan aktif dari suami, memiliki teknik menyusui yang baik dapat meningkatkan keberhasilan menyusui pada dua bulan pertama.

Menurut hasil penelitian Hikmawati (2008) jenis persalinan dapat mempengaruhi pelaksanaan IMD yang disebabkan karena adanya penggunaan obat kimia yang diberikan saat ibu melahirkan bisa sampai ke janin melalui ari-ari atau tindakan seperti operasi caesar. Vakum, vorcep, sehingga dapat mengganggu kemampuan alami bayi untuk mencari dan menemukan sendri payudara ibunya (Roesli, 2012).

Keberhasilan Inisiasi Menyusu Dini (IMD) Bayi juga dipengaruhi oleh kunjungan ibu hamil untuk melakukan pemeriksaan kehamilan kepada tenaga kesehatan (dokter dan bidan). Hal ini dapat dilihat pada Tabel 4.6 yang menunjukan bahwa responden yang periksa kehamilan ke petugas kesehatan (dokter dan Bidan) sebagian besar Pernah: teratur periksa kehamilan ke petugas kesehatan yaitu berjumlah 48 orang (96\%) dengan tingkat keberhasilan IMD yaitu berjumlah 26 orang (52\%) dan tingkat keberhasilan Asi Eksklusif yaitu berjumlah 31 orang (62\%).

Hasil penelitian menunjukkan dari 50 responden, yang memberikan ASI Eksklusif kepada bayinya adalah sebanyak 31 responden (62\%), sedangkan responden yang tidak memberikan ASI Eksklusif kepada bayinya adalah 19 
responden (38\%). Berdasarkan data tersebut menunjukkan bahwa sebagian besar responden memberikan ASI eksklusif kepada bayinya. Menurut RISKESDAS (2013) kreteria menyusu ekslusif ditegakan bila anak bila anak umur 0-6 bulan hanya diberi ASI saja pada 24 jam terakhir dan tidak diberi makanan dan minuman lain selain ASI. Pemberian ASI eksklusif ini dianjurkan selama 6 bulan merupakan rekomendasi terbaru UNICEF bersama World Health Assembly (WHA) dan banyak negara lainnya. Memberikan ASI pada bayi adalah sesuai dengan dorongan alamiahnya baik siang maupun malam (8-10 kali atau lebih dalam 24jam) selama bayi menginginkan. Manfaat pemberian ASI eksklusif adalah sebagai nutrisi pada bayi, meningkatkan daya tahan tubuh bayi, meningkatkan kecerdasan bayi serta meningkatkan jalinan kasih saying antara ibu dan bayi (Vetty dan Elamtris, 2011).

Hasil penelitian yang dilakukan oleh Vetty dan Elmatris (2011) tentang Hubungan Pelaksanaan Menyusui Dini Dengan Pemberian Asi Eksklusif Di Wilayah Kerja Puskesmas Tanah Garam Kota Solok memperlihatkan bahwa dari 189 ibu yang menjawab kuesioner hanya sebagian $(58,2 \%)$ yang memberikan ASI Eksklusif. Banyaknya responden yang memberikan ASI Eksklusif ini dipengaruhi oleh beberapa faktor. Komitmen ibu untuk menyusui dari awal sejak kehamilan merupakan faktor penting dalam pemberian ASI Eksklusif.

Pemberian ASI Eksklusif tidak terlepas dari pemberian ASI secara dini kepada bayi. Dengan melakukan manajemen laktasi maka upaya pemberian ASI Eksklusif akan lebih mudah dilakukan. Apalagi adanya penyuluhan tentang keuntungan dari ASI Eksklusif yang sudah dimulai sejak masa kehamilan. Ibu yang tidak memberikan ASI Ekslusif kepada bayinya juga dipengaruhi oleh beberapa faktor seperti air susu kurang sehingga bayi sering rewel dan menangis.

Kendala dalam pemberian ASI Eksklusif yaitu pemberian makanan dan minuman kepada bayi sebelum ASI keluar seperti madu dan susu formula dan ketidak percayaan ibu memberikan ASI kepada bayi. Disamping itu, gencarnya promosi susu formula juga termasuk salah satu gagalnya pemberian ASI Eksklusif (Vetty dan Elmatris, 2011). Roesli (2000) mengatakan ketidak berhasilan pemberian ASI Eksklusif tidak hanya dengan alasan ASI yang tidak cukup saja akan tetapi sikap ibu yang tidak mau menyusui bayinya dengan alasan takut di tinggal suami karena adanya mitos bahwa menyusui akan merusak bentuk payudara sehingga payudara tidak kelihatan bagus lagi.

Hasil penelitian juga menunjukan bahwa jumlah anak dapat menentukan keberhasilan asi eksklusif dilihat dari pengalaman ibu. Rata-rata informan asi 
ekslusif memiliki 3 anak sedangkan ratarata informan asi tidak eksklusif memiliki 2 anak(Fikawati dan Syafiq, 2009). Hal ini sejalan dengan hasil penelitian riwayat kehamilan dalam hal ini yang dilihat adalah jumlah anak menunjukkan bahwa jumlah anak satu yaitu berjumlah 12 orang (24\%), dua berjumlah 22 orang (44 $\%)$, dan $\geqslant$ tiga berjumlah 32 orang (32\%). Dalam Ekstron et al 2003 mengungkapkan bahwa ibu yang primipara lebih banyak yang menyusui bayi dibandingkan multipara tetapi pada ibu multipara lebih lama dapat memberikan Asi pada bayinya. Bayi baru lahir pada ibu primipara lebih banyak menerima cairan pengganti ASI pada minggu pertama setelah lahir $22,2 \%$ dari ibu primi para sedangkan bayi baru lahir yang mendapat cairan pengganti ASI pada minggu pertama setelah lahir sebanyak $18,7 \%$ dari ibu multipara.

Hasil uji statistik didapatkan nilai $p=0,001$. Hal ini menunjukkan terdapat hubungan antara variabel IMD (Inisisasi Menyusu Dini) dengan Pemberian Asi Eksklusif $(\mathrm{p}<0,05)$ sehingga Hipotesis $\mathrm{H}_{\mathrm{a}}$ diterima bahwa Ada hubungan antara Inisiasi Menyusu Dini dengan Keberhasilan Pemberian Asi Ekslusif 0-6 bulan di wilayah Kerja Puskesmas Kereng Pangi .

Hasil penelitian Juliastuti (2011) pada ibu nyang mempunyai bayi umur 612 bulan dengan jumlah sampel 85 responden, menunjukkan bahwa makin dilaksanakan IMD makan akan semakin tinggi pemberian Asi eksklusif $(\mathrm{p}=0,002)$.
Hal ini sejalan dengan hasil penelitian yang dilakukan oleh Jana (2015) tentang Hubungan Tingkat Pengetahuan Ibu Tentang Inisiasi Menyusu Dini (Imd) Dengan Partisipasi Ibu Melakukan IMD (Studi di Ruang Bersalin RS Wava Husada). Hasil dari penelitian ini menjelaskan bahwa adanya hubungan antara tingkat pengetahuan tentang Inisiasi Menyusu Dini dengan partisipasi ibu melakukan Inisiasi Menyusu Dini ( $p$ value $(0,009)<\alpha(0,05)$ dan $r=0,859)$.

Terdapat banyak penelitian lainnya yang telah dilakukan dengan hasil yang sama, yakni terdapat hubungan antara IMD dengan pemberian ASI eksklusif. IMD dapat meningkatkan angaka pemberian ASI eksklusif secara signifikan. Menurut fika dan syafig dalam jurnal kedokteran triakti mengatakan bahwa bayi yang diberi kesempatan menyusu dini, hasilnya delapan kali lebih berhasil asi ekskusif (Rusli, 2012). Angka pemberian ASI (secara eksklusif dan hampir eksklusif) meningkatkan secara signifikan pada kelompok bayi yang diberikan perlakuan IMD (85,3\%), dibandingkan dengan bayi yang tidak dilakukan IMD $(65,7 \%)$ (Mahmood et al., 2011). Hasil penelitian terhadap 121 responden juga menunjukkan bahwa ada perbedaan bermakna antara keberhasilan IMD terhadap lamanya pemberian ASI dengan nilai $\mathrm{p}=0,008$ (Rahayu, dkk, 2012). Pada penelitian tersebut tidak menilai keberhasilan ASI eksklusif melainkan lamanya pemberian lamanya pemerian ASI. 


\section{KESIMPULAN}

Berdasarkan hasil penelitian ini mengenai hubungan antara Inisiasi Menyusu Dini dengan keberhasilan pemberian Asi ekslusif didapatkan kesimpulan sebagai berikut:

a. Terdapat hubungan antara Inisiasi Menyusu Dini dengan keberhasilan pemberian Asi ekslusif di wilayah kerja puskesmas Kereng Pangi

b. Sebagian besar responden berada pada kelompok umur 20-35 tahun berjumlah 41 orang ( $82 \%$ ).

c. Mayoriritas responden dengan tingkat pendidikan SMP yaitu berjumlah 19 orang (38\%), SMA berjumlah 17 orang (34\%).

d. Sebagian besar responden pekerjaannya adalah ibu rumah tangga yaitu berjumlah 39 orang (76\%).

e. Sebagian besar responden mengalami persalinan normal yaitu berjumlah 43 orang (86\%).

f. Jumlah anak satu yaitu berjumlah 12 orang (24\%), dua berjumlah 22 orang (44\%), dan $\geqslant$ tiga berjumlah 32 orang (32\%).

g. Memeriksa kehamilan ke petugas kesehatan (dokter dan Bidan) sebagian besar Pernah: teratur periksa kehamilan ke petugas kesehatan yaitu berjumlah 48 orang (96\%).
Disarankan Puskesmas Kereng Pangi mengoptimalkan dan memonitoring program pelaksanaan IMD dan Asi Ekslusif. Serta meningkatkan program promosi kesehatan tentang Inisiasi Menyusu Dini dan Asi Ekslusif. Sesuai PP nomor 33 tahun 2012 tentang ASI ekslusif, merupakan langkah awal bagi Puskesmas Kereng Pangi untuk selalu proaktif melakukan advokasi dengan pemerintah daerah atau pihak terkait lainnya agar semua pihak dapat memberikan dukungan dalam membuat perda wajib Asi Ekslusif dan IMD di wilayah kerjanya.

b. Bagi Tenaga Kesehatan (Bidan dan Dokter)

Bagi tenaga kesehatan khususnya bidan harus memahami manfaat Inisiasi Menyusu Dini dan wajib mematuhi pelaksanaan Inisiasi Menyusui Dini pada setiap menolong persalinan. Dan juga disarankan untuk semua petugas kesehatan agar dapat berpartisipasi aktif dalam memberikan edukasi Asi Esklusif dan Inisiasi Menyusu Dini pada setiap ibu dimulai sejak kehamilan, saat persalinan dan nifas.

\section{SARAN}

a. Bagi Puskesmas 
c. Bagi Peneliti Selanjutnya

Bagi peneliti selanjutnya disarankan untuk dapat melakukan penelitian lebih mendalam lagi tentang hubungan IMD dengan Asi eksklusif dengan pendekatan yang lebih baik dan variabel yang berbeda.

\section{DAFTAR PUSTAKA}

Ambarwati R, Muis SF, Susanti P. Pengaruh konseling laktasi intensif terhadap pemberian air susu ibu (ASI) eksklusif sampai 3 bulan. Jurnal Gizi Indonesia. 2013;2(1).

Aprillia Y. Analisis Sosialisasi Program Inisiasi Menyusu Dini dan ASI Eksklusif kepada Bidan di Kabupaten Klaten. 2010.

Badan Pusat Statistik, BKKBN dan, Kementerian Kesehatan. Survei Demografi dan Kesehatan Indonesia (SDKI) 2012. Jakarta: Badan Pusat Statistik; 2013.

Badan Perencanaan Pembangunan Nasional (Bappenas RI). Program Nasional Bagi Anak Indonesia Kelompok Kesehatan. Jakarta: Bappenas; 2015.

Bramson L, Lee JW, Moore E, Montgomery S, Neish C, Bahjri K, et al. Effect of early skin-to-skin mother-infant contact during the first 3 hours following birth on exclusive breastfeeding during the maternity hospital stay. Journal of Human Lactation. 2010.

Crawl IOBBB. BREAST CRAWL. 2007.

Clinical Competencies of Practice for IBCLCs. In: International Board of Lactation Consultant Examiners, editor. http://iblceorg/wpcontent/uploads/2013/08/clinicalcompetencies-indonesian.pdf.
Departemen Kesehatan RI. Manajemen Laktasi; Buku Panduan bagi Bidan dan Petugas Kesehatan di Puskesmas. Departemen Kesehatan RI Direktorat Jendral Bina Kesehatan Masyarakat Direktorat Gizi Masyarakat Jakarta. 2005:8-10.

Departemen Kesehatan. Laporan Riset Kesehatan Dasar (RISKESDAS) 2010. Jakarta: Departemen Kesehatan RI. 2010.

Edmond KM, Zandoh C, Quigley MA, Amenga-Etego S, Owusu-Agyei S, Kirkwood BR. Delayed Breastfeeding Initiation Increases Risk of Neonatal Mortality. Pediatrics. 2006;117(3):e380e6.

Fikawati S, Syafiq A. Kajian implementasi dan kebijakan air susu ibu eksklusif dan inisiasi menyusu dini di Indonesia. Makara Kesehatan. 2010;14(1):17-24.

Ikatan Dokter Anak Indonesia. Pedoman Pelayanan Medis. Jakarta 2009.

Ikatan Dokter Anak Indonesia. Revitalisasi Rumah Sakit Sayang Bayi: Ikatan Dokter Anak Indonesia: 2013. Available from: http://www.idai.or.id/artikel/klinik/asi/r evitalisasi-rumah-sakit-sayang-bayi.

Keputusan Menteri Kesehatan RI No. 237/Menkes/SK/IV/1997 tentang Pemasaran Pengganti ASI.

Kemenkes RI No. 450/Menkes/SK/IV/2004 tentang Pemberian ASI secara Eksklusif pada Bayi di Indonesia.

Menteri Kesehatan Republik Indonesia. Keputusan Menteri Kesehatan Republik Indonesia Nomor 369. MENKES/SK/III/2007 Tentang Standar Profesi Bidan, 2007.

Noer ER, Muis SF, Aruben R. Praktik Inisiasi Menyusu Dini dan Pemberian ASI 
Eksklusif Studi Kualitatif pada Dua Peraturan Menteri Kesehatan No. Puskesmas, Kota Semarang. Media 240/MENKES/PER/V/1985 tentang Medika Indonesiana. 2011;45(3):144-50. Pengganti ASI.

Örün E, Yalçin SS, Madendag Y, Üstünyurt- Peraturan Pemerintah No. 69 Tahun 1999 Eras Z, Kutluk S, Yurdakök K. Factors Tentang Label dan Iklan Pangan, (1999). associated with breastfeeding initiation Roesli U. Panduan: inisiasi menyusu dini: plus time in a Baby-Friendly Hospital. The asi eksklusif: Pustaka Bunda; 2012.

Turkish journal of pediatrics. 2010;52(1):10.

Ready to submit your research? Choose INFOKES and benefit from:

- fast, convenient online submission

- $\quad$ thorough peer review by experienced researchers in your field

- rapid publication on acceptance

- $\quad$ support for research data

- Open Access which fosters wider collaboration and increased citations

- maximum visibility for your research

At Health Polytechnic of Kupang, research is always in progress.

Learn more http://jurnal.poltekkekupang.ac.id/index.php/infokes 